\title{
PENGARUH TIPE ROTIFER UNTUK PAKAN AWAL EKSOGEN TERHADAP MUTU BENIH BANDENG (Chanos chanos Forskal)
}

\author{
Agus Prijono", Gede Sumiarsa", dan Ngurah Sedana Yasa"m
}

\begin{abstract}
ABSTRAK
Rotifer merupakan pakan yang umum dipergunakan dalam pemeliharaan larva ikan bandeng tetapi diketahui terdapat beberapa tipe rotifer yang tersedia untuk pakan larva.

Tujuan dari penelitian adalah untuk mengetahui tipe rotifer yang cocok untuk meningkatkan mutu benih yang dihasilkan. Penelitian menggunakan wadah kaca serat sebanyak 9 buah ukuran $1 \mathrm{~m}^{3}$ yang diisi air laut 500 liter dan ditebar telur bandeng kepadatan 30 ekor/liter. Rotifer dari tiga tipe yaitu SS, S dan L digunakan sebagai perlakuan dan masing-masing perlakuan diulang 3 kali. Larva bandeng sejak berumur 2 hingga 5 hari diberi pakan rotifer dari masing-masing tipe dengan kepadatan 3-5 ind/ml dan selanjutnya diberi tipe S sampai larva berumur 21 hari.
\end{abstract}

Hasil penelitian menunjukkan bahwa pemberian rotifer tipe SS menunjukkan tingkat sintasan tinggi, yaitu sebesar $46,85 \%$ dan berbeda nyata $(P<0,05)$ dengan pemberian rotifer tipe S maupun L.

\begin{abstract}
Effect of Rotifer Type for First Exogenous Feeding on milkfish, Chanos chanos, Forskal Fry Quality. By: Agus Priyono, Gede Sumiarsa and Ngurah Sedana Yasa.

Rotifer is a commom zooplankton used in milkfish larval rearing but there have been several type of rotifer to be used.

The objective of the experiment was to find out the suitable type of rotifer to improve seed production of milkfish. The experiment was conducted in nine $1 \mathrm{~m}^{3}$ fibreglass tanks filled with 500 liters of sea water and stocked with 30 milkfish eggs/liter. Three types of rotifer i.e. SS, S and L were used as treatments with three replicates. The larvae were fed with each different type of rotifer with density of $3-5 \mathrm{ind} / \mathrm{ml}$ at 2 day after hatch $(\mathrm{DAH})$ up to $5 \mathrm{DAH}$. Afterwards, $\mathrm{S}$ type rotifer were given until $21 \mathrm{DAH}$. The result showed that the different types of rotifer significantly affect the survival rate of milkfish $(\mathrm{P}<0.05)$. The SS type rotifer resulted the highest survival rate of $(46.85 \%)$.
\end{abstract}

\section{KEYWORDS: Strain rotifer, exogenous, feed, survival rate, milkfish fry.}

\section{PENDAHULUAN}

Rotifer (Brachionus plicatilis) merupakan organisme dari golongan zooplankton dan jasad pakan penting bagi jenis ikan laut atau ikan air payau. Dalam usaha pembenihan ikan, rotifer sangat diperlukan untuk pakan awal larva yang baru menetas dan bahkan selama pemeliharaan pralarva hingga mencapai benih. Ketersediaan pakan rotifer erat kaitannya dengan keberhasilan suatu upaya pembenihan misalnya pada pemeliharaan larva ikan belanak (Tamaru et al. 1991), larva bandeng (Vanstone et al., 1977; Kumagai., 1984), larva kepiting (Rusdi et al., 1993; Yunus, 1992), dan larva ikan "red sea bream". Umumnya rotifer merupakan spesies yang dapat hidup pada rentang kadar garam yang tinggi. Ukurannya sangat bermacam-macam tergantung tempat hidupnya, suhu, salinitas dan tipenya. Rotifer dewasa ditemui mempunyai ukuran panjang 123$315 \mu \mathrm{m}$ (Arnold dan Holt, 1991). Sedangkan Liao et al. (1991) mengamati tipe $B$. plicatilis di tambak-tambak pemeliharaan dari tipe S (Small) dengan ukuran 100-305 $\mu \mathrm{m}$. Penelitian penggunaan rotifer untuk pakan larva awal ikan bandeng oleh Prijono et al. (1993) menggunakan rotifer tipe S (Small) berukuran antara 150-240 $\mu \mathrm{m}$ dapat menghasilkan sintasan larva sampai $50,05 \%$, namun diperoleh ukuran panjang dan bobot larva yang tidak seragam. Pentingnya

\footnotetext{
T) Peneliti pada Loka Penelitian Perikanan Pantai Gondol, Bali.

*) Mahasiswa Universitas Brawijaya, Malang, Jawa Timur.
} 
mengetahui berbagai jenis ukuran dan tipe rotifer terkait dengan penyediaan pakan awal larva bandeng yang ukuran bukaan mulutnya sangat tergantung pada umur larva dan variasi ukuran bukaan mulut saat memerlukan makanan alami, yang diketahui mulai makan umur dua hari. Oleh karena itu, pengaruh pemberian tipe rotifer yang ideal yang diberikan akan memperbaiki keragaan larva yang dipelihara. Terkait dengan beragamnya tipe rotifer perlu dilakukan penelitian peng. gunaan tipe rotifer yang berbeda pada masa awal pemberian pakan (exogenous) larva bandeng, yang diharapkan dapat memperbaiki mutu benih yang dihasilkan.

\section{BAHAN DAN METODE}

Penelitian pengaruh jenis rotifer pada masa awal eksogen pada pertumbuhan larva bandeng dilakukan di Loka Penelitian Perikanan Pantai Gondol.

Wadah penelitian yang digunakan, yaitu bak kaca serat volume $1 \mathrm{~m}^{3}$ dengan warna bak hitam diisi air laut bersalinitas 33 ppt sebanyak 500 liter yang dilengkapi dengan aerasi yang dioperasikan secara kontinyu selama penelitian. Wadah penelitian diletakkan di ruang yang beratap kaca serat dengan tingkat kecerahan antara 7500-15.000 lux cahaya pada siang hari.

Telur bandeng ditebar pada masing-masing bak dengan kepadatan 30 butir/liter. Perlakuan yang diuji adalah pemberian pakan dengan 3 macam tipe rotifer, yaitu (A) tipe SS (Super Small, panjang lorica 80-130 $\mu \mathrm{m}$ ), (B) tipe S (Small, panjang lorica 110-230 $\mu \mathrm{m}$ ) dan (C) tipe L (Large, panjang lorica $160-330 \mu \mathrm{m}$ ), masingmasing perlakuan diulang 3 kali. Untuk mengetahui pengaruh tipe rotifer terhadap masa awal eksogen tiga tipe rotifer tersebut diberikan mulai berumur 2 hari sampai mencapai umur 5 hari, pada hari berikutnya larva diberi pakan rotifer dari tipe $\mathrm{S}$ saja hingga larva berumur 21 hari (siap panen). Untuk mengetahui pengaruh rotifer yang diberikan dilakukan penghitungan dengan rancangan acak lengkap dan untuk membedakan masing-masing perlakuan dilakukan uji LSD dengan selang kepercayaan 95\%. Jumlah rotifer untuk pakan larva didasarkan pada tingkatan umur larva antara lain: larva umur 2 sampai 5 hari diberi pakan dengan kepadatan $3-5 \mathrm{ind} / \mathrm{ml}$, selanjutnya pada umur 5-10 diberi rotifer kepadatan 5-15 ind/ml dan larva umur 11-15 diberi rotifer kepadatan 15-20 ind/ml dan larva umur 16 hari sampai panen diberi rotifer kepadatan 25-30 ind/ml. Selain rotifer sebagai pakan utama juga diperlukan Nannochloropsis dengan kepadatan $10^{6} \mathrm{sel} / \mathrm{ml}$ yang diberikan pada larva mulai umur 2 hari sampai menjelang panen (umur 21 hari). Selama perawatan larva dilakukan pengaturan pergantian air, yaitu mulai larva berumur 8-10 hari air diganti $\pm 30 \%$. Kemudian setiap dua hari air diganti sebanyak $50 \%$ sampai selesai penelitian.

Pengamatan pertumbuhan dilakukan setiap 5 hari dan sintasan dihitung setelah dilakukan panen. Pengamatan jumlah rotifer yang termakan diamati pada 5 ekor larva dengan mikroskop. Pengamatan kualitas air dilakukan pada masa awal pemberian pakan, saat perubahan pakan (hari ke-5) dan setiap 5 hari hingga menjelang akhir penelitian yang meliputi suhu, $\mathrm{pH}$, salinitas, fosfat, oksigen dan nitrit.

\section{HASIL DAN PEMBAHASAN}

\section{Pertumbuhan Panjang dan Bobot Larva}

Hasil pengamatan pertumbuhan panjang larva bandeng dari 3 perlakuan pemberian pakan tipe rotifer berbeda selama 21 hari tidak me. nunjukkan perbedaan yang nyata pada $\mathrm{P}>0,05$. (Table 1).

Larva yang memakan rotifer dari tipe $\mathrm{S}$ dan SS tumbuh lebih cepat dari pada larva memakan rotifer tipe L. Tingginya nilai pertumbuhan panjang pada larva yang makan rotifer tipe SS dan $\mathrm{S}$ karena larva dapat makan rotifer yang lebih kecil dari bukaan mulut larva, terbukti dari pengamatan mikroskopis isi lambung larva selalu didapatkan rotifer yang dimakan cukup banyak, yaitu antara 3-6 ind/larva untuk yang memakan tipe SS dan 2-5 ind/larva untuk larva yang memakan rotifer tipe $S$, berbeda dengan larva yang memakan rotifer tipe $\mathrm{L}$ isi lambung tidak nampak adanya rotifer, namun ditemui telurtelur rotifer sejumlah 2-3 butir/larva. Nampaknya rotifer yang dimakan oleh larva mengandung nilai gizi tinggi karena mempunyai kandungan protein sebesar $69,28 \%$ (Table 2), hal tersebut didukung oleh penelitian Tobias et al. (1982) bahwa rotifer hidup mengandung protein sebesar $55,21 \%$, sementara protein rotifer kering sebesar $48,6 \%$. 
Prijono, A.i Sumiarsa, G. dan Yasa S.

Table 1. Averages of total length, weight and survival of milkfish larvae after 21 days fed by different type of rotifer (SS, S and L)

\begin{tabular}{cccc}
\hline Treatment & $\begin{array}{c}\text { Total length } \\
(\mathrm{cm})\end{array}$ & $\begin{array}{c}\text { Weight } \\
(\mathrm{mg})\end{array}$ & $\begin{array}{c}\text { Survival } \\
(\%)\end{array}$ \\
\hline Type SS & $12.28^{a}$ & $5.75^{a}$ & $46.85^{\mathrm{c}}$ \\
Type S & $12.14^{a}$ & $5.98^{a}$ & $37.59^{\mathrm{b}}$ \\
Type $L$ & $13.47^{a}$ & $8.37^{\circ}$ & $4.23^{a}$ \\
\hline
\end{tabular}

Note: values in the column followed by similar letter are not significantly different (P>0.05)

Table 2. Proximate analysis and fatty acid profile of rotifer type SS, $S$ and $L$.

\begin{tabular}{lccc}
\hline \multicolumn{1}{c}{ Component (\%) } & Type SS & Type S & Type L \\
\hline Moisture & 7.85 & 8.64 & 3.58 \\
Protein & 44.83 & 69.28 & 56.82 \\
Fat & 6.16 & 9.22 & 8.68 \\
Ash & 10.76 & 6.66 & 2.44 \\
Others & 30.40 & 6.20 & 28.48 \\
$14: 0$ & 0.19 & 5.80 & 6.51 \\
$16: 0$ & 21.68 & 39.02 & 36.18 \\
$18: 0$ & - & - & - \\
$18: 1 \omega-9$ & 25.10 & 17.32 & 15.59 \\
$18: 2 \omega-6$ & 9.84 & 13.28 & 12.56 \\
$18: 3 \omega-3$ & 4.28 & 1.53 & 1.91 \\
$20: 4 \omega-6$ & 6.03 & 3.56 & 4.09 \\
$20: 5 \omega-3$ & 18.24 & 12.18 & 14.34 \\
$22: 6 \omega-3$ & 14.61 & 7.30 & 8.81 \\
\hline Total $\omega-3$ HUFA & 37.13 & 21.01 & 25.06 \\
\hline
\end{tabular}

Hasil analisis asam lemak tak jenuh (HUFA) menunjukkan bahwa rotifer tipe SS mengandung asam lemak tak jenuh sebesar $37,13 \%$ lebih tinggi dari $\mathbf{S}$ maupun L. Sementara kandungan asam lemak tak jenuh 20:4 $\omega-6$ sebesar 6,03\% (Table 2) lebih besar dari pengamatan Hirayama dan Satuito (1991), yaitu sebesar 2,9\%. Tingginya nilai asam lemak tak jenuh sangat besar manfaatnya untuk metabolisme termasuk pertumbuhan dan mempertahankan sintasan larva Kanazawa et al. (1985). Demikian pula Tamaru et al. (1991) menyebutkan bahwa dari hasil analisis asam lemak berupa EPA dan DHA sebesar berturut-turut 1,25 dan $0,51 \mathrm{mg} / 100 \mathrm{mg}$ 
bobot kering rotifer banyak digunakan untuk pemberian pakan awal larva ikan belanak (Mugil cephalus) dan dapat meningkatkan sintasan sampai $55,5 \%$. Ditinjau dari hasil analisis asam lemak dari rotifer yang digunakan sebagai pakan nampak kandungan HUFA rotifer tipe SS cukup tinggi mencapai 37,13\% (Table 2), Kandungan HUFA tersebut diduga dapat mempercepat pertumbuhan karena kebutuhan EPA dan DHA larva untuk tumbuh mampu dipenuhi oleh rotifer yang dimakan, maka larva yang kurang makan tumbuhnya terhambat. Karena kemampuan larva untuk memakan rotifer sangat terkait dengan besarnya rotifer dan ukuran bukaan mulut larva, cenderung perlakuan pemberian rotifer dari tipe SS dan $\mathbf{S}$ mempunyai pertumbuhan bobot yang lebih tinggi dari larva yang diberi rotifer tipe $L$. Sehingga dari perhitungan statistik diketahui bahwa larva yang diberi pakan tipe SS tidak berbeda nyata dengan perlakuan tipe $S(P>0,05)$ dan berbeda nyata dengan perlakuan yang diberi pakan tipe $L(P<0,05)$ (Table 1). Pengamatan pertumbuhan panjang dan bobot larva yang diberi pakan tipe SS dan S setelah hari ke 15 nampak normal, sementara larva yang diberi pakan rotifer tipe $\mathrm{L}$ tumbuh lebih pesat hingga menjelang panen umur 21 hari. Pesatnya pertumbuhan diduga karena pakan yang tersedia mampu memenuhi kebutuhan untuk hidup (Figure 1).

\section{Sintasan}

Hasil pengamatan sidik ragam terhadap sintasan menunjukkan perbedaan yang sangat nyata $(P<0,05)$ antara perlakuan yang diberi pakan tipe rotifer berbeda. Sintasan tertinggi terjadi pada larva yang diberi pakan rotifer tipe SS yaitu sebesar $46,85 \%$ dan sintasan yang terendah terjadi pada larva yang diberi pakan rotifer tipe L selama 5 hari, yaitu sebesar $4,23 \%$. Dari data tersebut dapat diduga bahwa kematian massal larva terjadi pada larva berumur sekitar 5 hari. Padahal secara biologis pemanfaatan makanan akan terjadi menjelang hari ke-3 setelah larva menetas karena saat tersebut merupakan masa perubahan makanan dari habisnya kuning telur dan masuknya pakan dari luar (Tamaru et al., 1991). Masa kritis larva umumnya akan terjadi pada hari ke-3 setelah menetas, dan bahkan akan mengalami kematian massal setelah hari ke- 7 apabila mengalami kekurangan pakan atau tidak memadainya ukuran pakan yang diberikan, hal ini terbukti dari larva yang diberi pakan rotifer tipe L. Kematian larva ditandai dengan kondisi fisik larva yang tampak lemah dan berenangnya sangat lamban dan mudah stres oleh goncangan fisik air saat pergantian air maupun pemberian pakan. Lemahnya fisik larva secara makro mempunyai ukuran lebih kecil, badan memucat dan berenangnya tidak stabil. Pengaruh besarnya ukuran pakan awal yang diberikan akan menyebabkan rendahnya sintas. an. Pakan awal yang sesuai ukurannya merupakan salah satu faktor yang dapat meningkatkan sintasan larva, terbukti bahwa ukuran mulut larva bandeng awal antara 200-240 $\mu \mathrm{m}$ (Prijono, 1991) dan akan membesar sampai ukuran 400 $600 \mu \mathrm{m}$ pada larva umur 11-21 hari. Di lain pihak, Aslianti et al. (1993) menyatakan bahwa ukuran panjang lorica rotifer tipe L adalah 280 . $330 \mu \mathrm{m}$. Keadaan demikian yang kemungkinan menyebabkan larva banyak mengalami kematian. Dari pengamatan pemberian pakan rotifer pada masa awal eksogen menunjukkan perbedaan yang mencolok terutama pada masa awal pem. berian rotifer tipe SS dan S untuk pakan awal larva dan efektif digunakan untuk meningkatkan sintasan larva bandeng karena rotifer tipe SS dan $S$ mempunyai ukuran panjang lorica lebih kecil dibandingkan bukaan awal mulut larva. Ditinjau dari keragaan larva yang mendapat perlakuan pakan rotifer tipe SS dan S hasilnya lebih baik dan mempunyai ukuran seragam bila dibanding. kan dengan larva yang diberi pakan rotifer tipe $\mathrm{L}$.

\section{Kualitas Air}

Dari pengamatan kualitas air antara lain suhu, oksigen, fosfat, $\mathrm{pH}$ dan salinitas nampaknya tidak mempengaruhi kehidupan larva karena masih berada pada batas yang normal untuk kehidupan larva bandeng (Table 3).

Sedangkan nitrit dan nitrat mempunyai nilai yang cukup tinggi lebih dari 1,0 ppm. Naiknya kandungan nitrit dan nitrat terjadi setelah larva berumur lebih dari 10 hari, hal tersebut disebabkan penambahan Nannochloropsis setiap hari. Sehingga nampak sebagian besar larva pada perlakuan pemberian rotifer tipe SS, S dan L banyak yang mati dan terjadinya pembusukan dan mengakibatkan turunnya mutu air pemeliharaan. 
Prijono, A.; Sumiarsa, G. dan Yasa S.

Total length (mm)

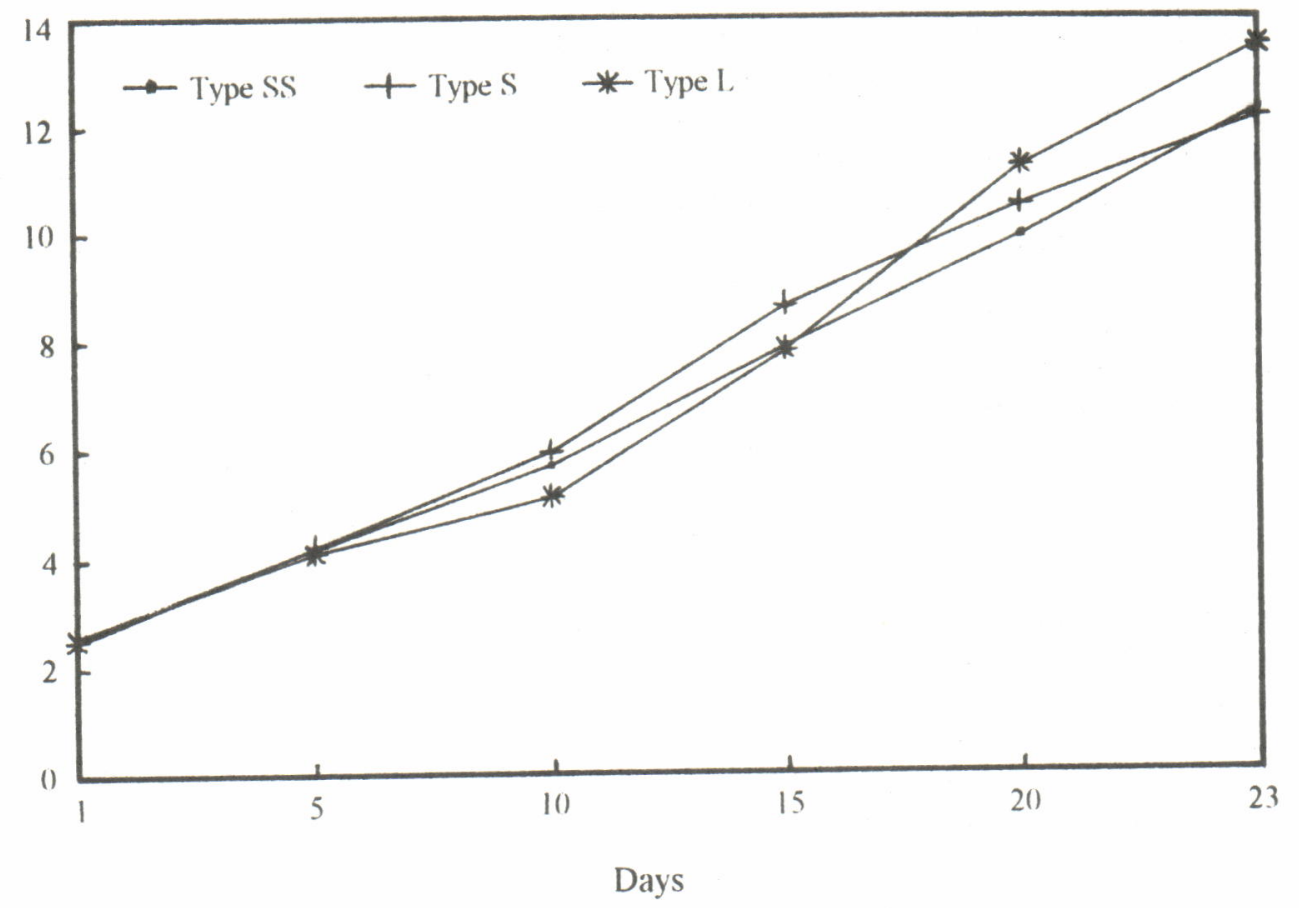

Weight (mg)

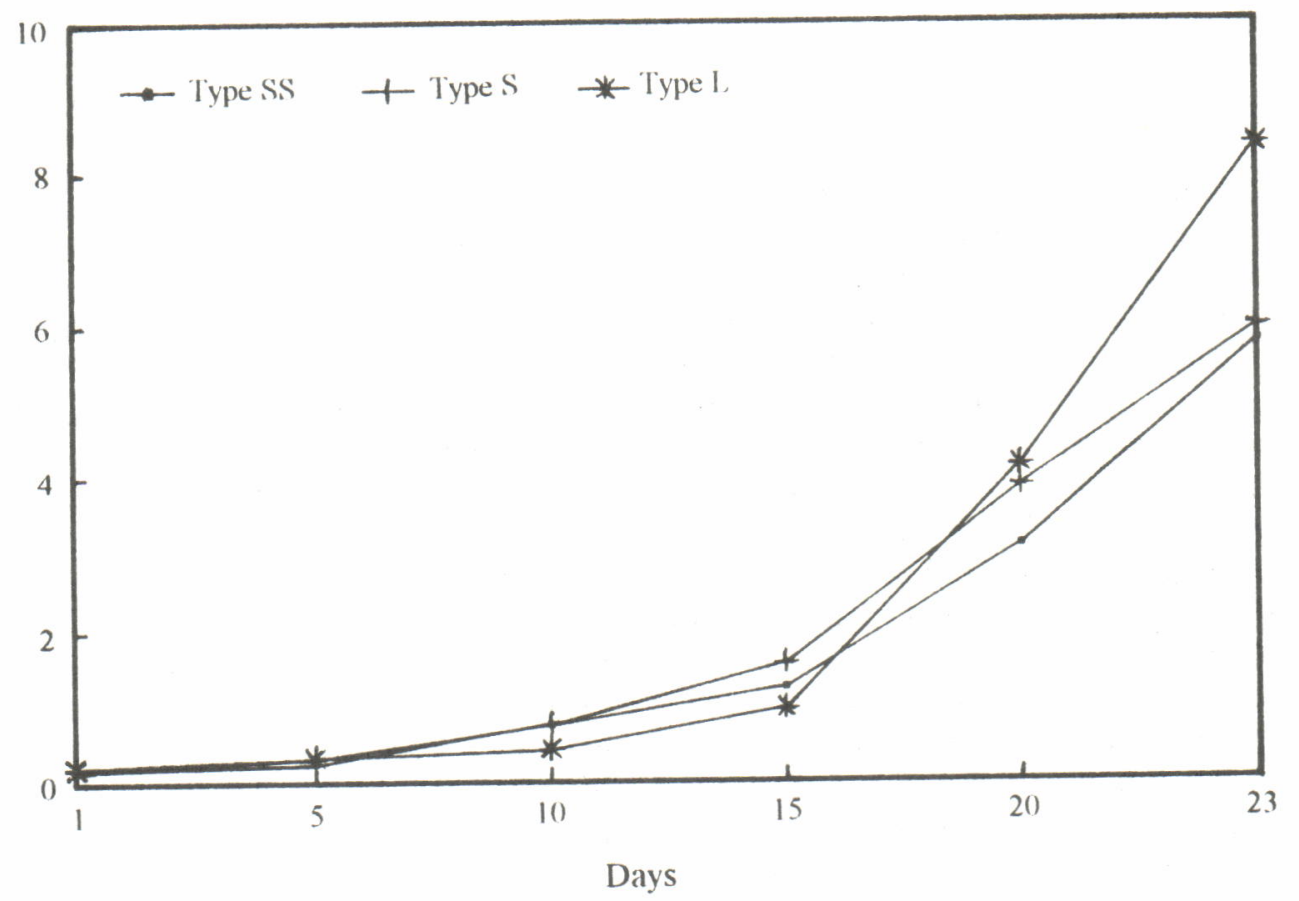

Figure 1. Length and weight of larvae fed with type SS, S and L rotifer. 
Table 3. Range of temperature, oxygen, nitrite, nitrate, phosphate, $p H$ and salinity of water during rearing of milkfish larvae fed with different strain of rotifer.

\begin{tabular}{lcccc}
\hline \multicolumn{1}{c}{ Treatment } & & Type SS & Type S & Type L \\
\hline Temperature & $\left({ }^{\circ}\right.$ C) & $26.0-28.0$ & $26.0-28.1$ & $26.0-28.3$ \\
Oxygen & $(p p m)$ & $6.95-7.80$ & $6.93-7.36$ & $6.66-7.05$ \\
Nitrite & $(p p m)$ & $0.01-1.05$ & $0.01-2.54$ & $0.01-1.14$ \\
Nitrate & $(p p m)$ & $2.23-2.27$ & $1.98-2.72$ & $2.59-2.69$ \\
Phosphate & $(p p m)$ & $0.10-1.38$ & $0.12-0.18$ & $0.11-0.13$ \\
pH & & $8.01-8.26$ & $8.12-8.17$ & $8.10-8.17$ \\
Salinity & $(p p t)$ & $25.0-26.0$ & $25.0-26.0$ & $25.0-26.0$ \\
\hline
\end{tabular}

\section{KESIMPULAN}

Pakan rotifer tipe SS menunjukkan sintasan larva yang berbeda nyata $(\mathrm{P}<0,05)$ dengan larva yang diberi pakan tipe $S$ maupun $L$. Tingkat sintasan larva tertinggi dicapai pada perlakuan pemberian rotifer tipe SS yaitu sebesar $46,85 \%$. Sehingga pakan yang cocok pada masa awal eksogen larva adalah rotifer dari tipe SS.

\section{UCAPAN TERIMAKASIH}

Terima kasih disampaikan pada teknisi litkayasa pembenihan bandeng Sdr. Dedi Rohaniawan, Putu Oka Suarjana, Agus Supriyatna yang telah banyak membantu dalam penyiapan pakan alami serta terima kasih pada teknisi litkayasa analis Sdr. Darsudi, Ayu Kenak dan Ari Arsini dan pada teknisi lainnya yang telah banyak mem. bantu dalam pelaksanaan penelitian.

\section{DAFTAR PUSTAKA}

Arnold, Cr.R., and G.J. Holt. 1991. Various method for the culture of rotifer, Brachionus plicatilis in Texas. In: Fulks, W and K.L Main (Eds)., Rotifer and microalgae culture systems. Proceedings of A. U.S. Asia Workshop, Honolulu, The Oceanic Institute, Honolulu, Hawaii.

Aslianti.T., A. Prijono, dan T. Ahmad. 1993. Pengaruh pemberian pakan alami dan pakan buatan terhadap sintasan larva bandeng Chanos chanos Forskal. J. Penelitian Budidaya Pantai 9 (1): 81-89.

Hirayama, K. and C.G. Satuito. 1991. The nutritional improvement of baker's yeast for the growth of the rotifer, Brachionus plicatilis. In W.Fulks and K.L
Main (Eds.), Rotifer and microalgae culture systems. Proceedings of A. U.S-Asia Workshop, Honolulu, The Oceanic Institute, Honolulu, Hawaii. p. 151-162.

Kanazawa, A., S. Teshima., M. Yamashita, and R. Hirakawa. 1985. Protein source in the microparticulate diets of Ayu fish. In A. Kanazawa (Ed.), Nutritional factor in fish reproduction and culture of milkfish. Proceedings for a Workshop held at Tungkang Marine Laboratory, Taiwan.

Kumagai, S. 1984. The ecological aspect of milkfish fry occurence, particularly in the Philippines. p. 55-58. In: J.V. Juario, R.P. Ferrarioes and L.V. Benites (Eds). Advance in Milkfish Biology and Culture. Island Publishing House. Inc. Metro Manila. Philippines pp: 55-58.

Liao, I.C., M.S. Su, and H. M. Su. 1991. An overview of live feeds production system design in Taiwan. In: W. Fulks and K.L Main (Eds.), Rotifer and microalgae culture systems. Proceedings of a. U.S-

Asia Workshop, Honolulu, The Oceanic Institute, Honolulu, Hawaii.

Prijono, A. 1991. Pembenihan bandeng di Indonesia. Materi mengajar siswa Sekolah Pertanian Pembangunan Blambangan, dalam rangka pemantapan pengalaman belajar. Sub Balai Penelitian Budidaya Pantai Gondol, 14 hal.

Prijono, A., T. Aslianti, dan D. Rohaniawan. 1993. Pengaruh waktu pemberian rotifer terhadap sintasan larva bandeng, Chanos chanos Forsskal. J. Penelitian Budidaya Pantai 9 (3): 67-71.

Rusdi,I., A. Parenrengi, dan D. Makatutu. 1993. Pengaruh perbedaan salinitas terhadap penetasan dan sintasan zoea awal kepiting bakau, Scylla serrata. J. Penelitian Budidaya Pantai 9 (1): 141 146 . 
Prijono, A.; Sumiarsa, G. dan Yasa S.

Tamaru, C.S., C.S. Lee and H. Ako. 1991. Improving the larval rearing of striped mullet (Mugil cephalus) by manipulating quantity and quality of the rotifer, Brachionus plicatilis. In W. Fulks and Main (Eds.), Rotifer and microalgae culture system. Proc. of A U.S.- Asia workshop. The Oceanic Institute, Honolulu, Hawaii. p. 89-103.

Tobias, E., Quinitio, and T.V.Cesar. 1982. Growth, survival and micronutrient composition of Penaeus monodon Fabricius larva fed with Chaetocheros calcitrans and Tetraselmis chuii. Aquaculture
Department, SEAFDEC, Iloilo, Philippines. P. 253260.

Vanstone,W.E, L.B. Tiro, Jr.A.C. Villaluz, D.C. Ramsingh, S. Kumagai., P.J. Dulduco., M.M. Barnes, and C.E. Duenas. 1977. Breeding and larval rearing of the milkfish Chanos chanos (Pieces: Chanidae). SEAFDEC Tech. Report 3: 3-17.

Yunus. 1992. Pemeliharaan larva kepiting bakau, Scylla serrata dengan beda kepadatan rotifer, Brachionus plicatilis. J.Penelitian Budidaya Pantai 8 (2): 9-14. 